\title{
THE EFFECT OF NUMBER OF EXCITATION (NEX) VARIATION AND BLADE TECHNIQUE ON T2 IMAGE QUALITY TSE SAGITAL KNEE MRI
}

\author{
Fella Ustia Nirmala \\ Program Studi S1 Fisika, Fakultas Sains dan Teknologi, Universitas Airlangga \\ Email: fellaustianirmala@ gmail.com
}

\begin{abstract}
The research has been conducted entitled Influence of Variation Number of Excitation (NEX) and BLADE Technique on Image Quality T2 TSE Sagital Knee MRI. This research was conducted at Haji General Hospital Surabaya by using MRI 1.5 Tesla modalities. The usage of BLADE technique combined with the NEX 1 and NEX 2 variations performed on sagittal tissue of the knee and using a Turbo Spin Echo (TSE) sequence with T2 weighting. Data analysis was done quantitatively by using Region of Interest (ROI) method on MRI computer then analyzed Sinyal to Noise Ratio (SNR) and Contrast to Noise Ratio (CNR). From the research, good image quality result obtained by using BLADE technique on NEX 2 variation with SNR of tissues was 130,71 for Fluid, 5,54 for Meniscus, 12,88 for Anterior Cruciate Ligament (ACL) and 5,95 for Posterior Cruciate Ligament (PCL), whereas the CNR value of tissues was 125.16 for fluid-meniscus, 117.82 for ACL-fluid and 124.76 for fluid-PCL.
\end{abstract}

Keywords : NEX, TSE, T2 weighting, MRI Knee. 


\section{Latar Belakang}

Radiologi merupakan ilmu kedokteran yang digunakan untuk melihat jaringan tubuh manusia menggunakan radiasi gelombang mekanik ataupun gelombang elektromaknetik. Radiodiagnostik merupakan salah satu dari cabang ilmu radiologi yang memanfaatkan sinar pengion yang berbahaya jika mengenai pasien secara kontinu atau biasa disebut sinar X seperti X-Ray, CT scan, fluoroscopy, angiografi, dan mammografi. Namun seiring berkembangnya teknologi modern, tercipta suatu alat scanning seperti ultrasonography (USG) dan juga MRI (magnetic resonance imaging).

MRI adalah suatu alat yang menghasilkan citra potongan tubuh pada manusia yang menggunakan medan magnet. MRI memberikan efek kontras yang sangat baik pada jaringan-jaringan tubuh manusia yang berbeda-beda, seperti otot, jantung, otak, dan kanker. Alat tersebut dapat membuat potongan gambaran sagital, aksial, koronal dan oblik tanpa harus banyak memanipulasi tubuh pasien (woodward, 1997). Sehingga mempermudah bagi seorang dokter untuk mendiagnosa suatu penyakit terhadap pasien. 
(C) (2019) Sekolah Pascasarjana Universitas Airlangga, Indonesia

Teknik pencitraan yang dilakukan oleh Turbo Spin Echo (TSE) atau yang disebut MRI relatif lebih kompleks karena citra yang dihasilkan bergantung pada banyak tidaknya juga Fast Spin Echo (FSE) merupakan salah satu turunan dari pulsa spin echo (SE) dengan parameter yang digunakan. Jika pemilihan pada parameternya tepat, kualitas pencitraan detail dari tubuh manusia tersebut akan tampak jelas, sehingga anatomi dan patologi di jaringan tubuh dapat dievaluasi dengan teliti. Untuk dapat memperoleh citra yang baik maka harus mempertimbangkan sekuensekuen dan kontras pada jaringan yang akan didiagnosa dengan menentukan parameter Time Repetition (TR), Time Echo (TE), Echo Train Length (ETL), Number of Excitation (NEX), Slice thickness dan masih banyak parameter yang dapat mempengaruhi hasil citra MRI (Notosiswoyo dan Suswanti ,2004). Namun kualitas citra MRI sendiri disusun oleh tiga hal yaitu, CNR, spasial resolusi, dan SNR (Rochmayanti dkk, 2013). Parameter disini merupakan suatu pilihan yang terdapat dalam aplikasi komputer MRI dimana parameter ini dapat mempengaruhi kualitas yang ada pada gambar pemeriksaan MRI. 
memiliki waktu scan yang cepat. Pada TSE pemberian pulsa dengan satu kali pulsa $90^{\circ}$ diikuti dengan multiple $180^{\circ}$ rephasing dalam satu time repetition (TR).

NEX merupakan suatu nilai yang menunjukkan berapa kali munculnya data itu tercatat dan akan di masukkan ke matriks atau bisa di namakan akuisisi data dengan fase encoding dan amplitudo yang sama. Sejumlah data yang tercatat oleh $\mathrm{k}$-space akan di kontrol oleh NEX. Data tersebut terdiri dari sinyal dan noise. Nilai NEX yang tinggi berpengaruh pada SNR, dimana proses pengulangan munculnya data tanpa pengubahan fase encoding menyebabkan peningkatan amplitudo sinyal secara linear (Westbrook, 2011). Penggunaan variasi nilai NEX ini berpengaruh juga pada waktu pemeriksaan dan kualitas citra. Semakin meningkat nilai NEX maka semakin lama waktu pemeriksaan dengan mendapatkan citra yang baik. Sebaliknya ketika nilai NEX menurun maka waktu pemeriksaan akan lebih cepat, tetapi mendapatkan citra yang kurang baik bahkan tidak bagus (Rochmayanti dkk, 2010).

Pasien_yang tidak kooperatif seperti Ketika merasakan sakit pada jaringan lutut 
dalam menjalankan pemeriksaan terkadang tidak sengaja maupun tidak sadar menimbulkan suatu gerakan cenderung menyebabkan artefak gerak kecuali proses scanning bekerja sangat cepat. Teknik akuisisi baru yang dapat digunakan disini memiliki kelebihan untuk mengurangi bahkan menghilangkan artefak dari efek gerak pasien. Teknik ini dikenal sebagai BLADE yang berkontribusi besar terhadap artefak distorsi biasa. NEX digunakan sebagai rata-rata keluaran artefak untuk mengurangi fase ghosting, tapi mengarah ke lebih lama waktu pemeriksaan (Westbrook, Catherine, 2010). Teknik BLADE telah diperkenalkan untuk mengurangi gerak artefak dan meningkatkan kualitas gambar (Alibek, 2008). Serupa dengan temuan ini diperkenalkan dalam pemeriksaan dari atas perut (Hirokawa, 2008) dan lutut (Lavdas, 2012) pasien. Sehingga variasi NEX akan sangat diperlukan dengan menggabungkan teknik BLADE dengan meningkatkan rekonstruksinya untuk mengurangi hasil motion artefak tersebut dan menghasilkan kualitas citra yang baik untuk pemeriksaan pada cedera lutut, dimana penelitian ini 
meninjau lebih dalam mengenai cedera lutut yang sering terjadi pada ligamennya.

Dalam penelitian ini akan dilakukan studi kasus untuk mencari variasi NEX dan BLADE pada rentang tertentu untuk pemeriksaan MRI cedera lutut karena dalam pengaplikasiannya parameter NEX pada Rumah Sakit yang memiliki Instalasi Radiologi masih menggunakan teknik CARTESIAN yang merupakan suatu proses pemasukkan data dari hasil akuisisi ke K-space mengikuti sumbu kartesius searah sumbu $\mathrm{X}$ sepanjang sumbu Y, tetapi teknik tersebut sangat rentan terhadap pergerakan dan ini yang terjadi kenyataan di lapangan bahwa teknik cartesian itu dipakai sebagai sekuen TSE rutin pada pemeriksaan MRI lutut. Parameter suatu citra dikatakan optimal adalah dengan ditunjukkan nilai SNR dan CNR yang tinggi serta waktu pemeriksaan yang tidak terlalu lama. Oleh karena itu, penelitian ini sangat penting untuk dilakukan melihat pengaruh nilai NEX dan BLADE dalam pemeriksaan MRI sangat besar serta kasus cedera lutut sendiri pada rumah sakit memiliki presentase pemeriksaan cukup besar sekitar 50\%. Menurut Lavdas dkk (2012) teknik BLADE diperkenalkan pada lutut untuk menghilangkan motion artefak pada citra gambar mengingan terdapat dua tipe pasien yaitu, kooperatif dan nonkooperatif. Pasien kooperatif merupakan pasien yang mudah diatur atau tidak banyak gerak, sedangkan pasien nonkooperatif merupakan pasien yangsulit untuk diatur atau banyak gerak yang bisa disebabkan karena 


\section{Pengaruh Variasi NEX dan Perlakuan Teknik pada SNR dan CNR}

Dari data hasil penelitihan yang diperoleh pada Nilai SNR yang mendapatkan nilai tertentu menunjukkan bahwa pengaruh dari perlakuan teknik Cartesian maupun teknik BLADE dan Variasi NEX terhadap nilai SNR tidak linier. Karena adanya perbedaan struktur molekul pada setiap jaringan sehingga mempengaruhi nilai dari SNR dan CNR. Banyaknya atom Hidrogen yang ada dalam tubuh juga dipengaruhi oleh usia pasien, dimana nilai SNR dan CNR akan tinggi ketika jaringan yang dianalisis memiliki jumlah atom Hidrogen yang banyak.

\section{Pada penggunaan teknik}

Cartesian dengan variasi NEX

tinggi menghasilkan SNR dan CNR

tinggi, akan tetapi hasil SNR dan

CNR lebih tinggi 
dan semakin bagus citra ketika

menggunakan teknik BLADE dengan

menggunakan nilai NEX besar yang

pada penelitihan ini digunakan nilai

NEX 2.

\subsubsection{Pengaruh Variasi NEX dan Perlakuan Teknik pada Waktu Scanning}

Waktu Scanning dapat

meningkat ketika mengalami

pengulangan, hal ini disebabkan

karena waktu scanning merupakan

waktu pelengkap untuk melengkapi

akuisisi data. Ketika dilakukan

pengulangan pada akuisisi data

sebanyak dua kali maka waktu

scanning juga akan meningkat dua

kalinya dan akan terjadi pengulangan

seterusnya. Disamping lamanya

waktu scanning yang diperlukan

ketika menggunakan pengulangan

akuisisi data maka kesemptan pasien

untuk bergerakpun semakin besar,

sehingga sedikit saja gerakan maka

kualitas citra akan menurun. Akan

tetapi waktu scanning ini juga sangat penting untuk mengontrol kualitas

suatu citra MRI sehingga dipadukan dengan teknik BLADE untuk

memperbaiki citra.

Pada penelitian ini waktu scanning meningkat secara linier seiring meningkatan nilai NEX, yakni dengan penggunaan NEX 2 dengan perlakuan teknik yang diberikan memerlukan waktu lebih lama dibandingkan dengan menggunakan nilai NEX 1 dengan perlakuan teknik yang diberikan. Korelasi bernilai positif, berarti kenaikan NEX menaikkan waktu scanning dengan hasil $\quad 1,744$ menit ketika menggunakan NEX 1 dan 3,4 menit ketika menggunakan NEX 2. 


\subsection{Penentuan Nilai Optimal Variasi NEX dan perlakuan Teknik terhadap}

\section{Kualitas Citra}

Untuk menentukan nilai yang paling optimal pada variasi NEX dan perlakuan teknik yang diberikan diperoleh dari grafik yang menunjukkan nilai SNR dan CNR yang tinggi. Grafik yang terbentuk merupakan akibat pengaruh dari variasi NEX dan pemberian teknik sehingga pemilihan yang tepat pada variasi NEX dan teknik perlu dipertimbangkan untuk mendapatkan nilai SNR dan CNR yang tinggi. Grafik pengaruh variasi NEX dan perlakuan ternik terhadap SNR dan CNR untuk keempat pasien ditunjukkan oleh Gambar 4.11 sampai 4.14 .

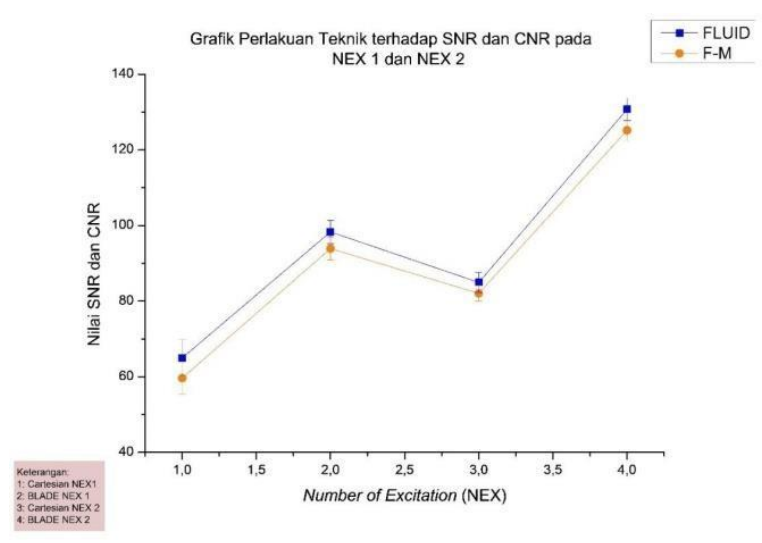

Gambar 4.11 Grafik

Hubungan Pengaruh Teknik

Cartesian dan Teknik

BLADE terhadap Nilai SNR dan CNR pada NEX 1 dan NEX 2 pada pasien 1 .

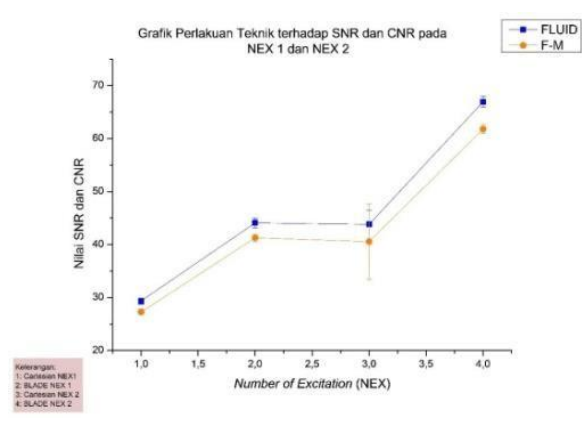

Gambar 4.12 Grafik

Hubungan Pengaruh Teknik Cartesian dan Teknik

BLADE terhadap Nilai SNR dan CNR pada NEX 1 dan NEX 2 pada pasien 2.

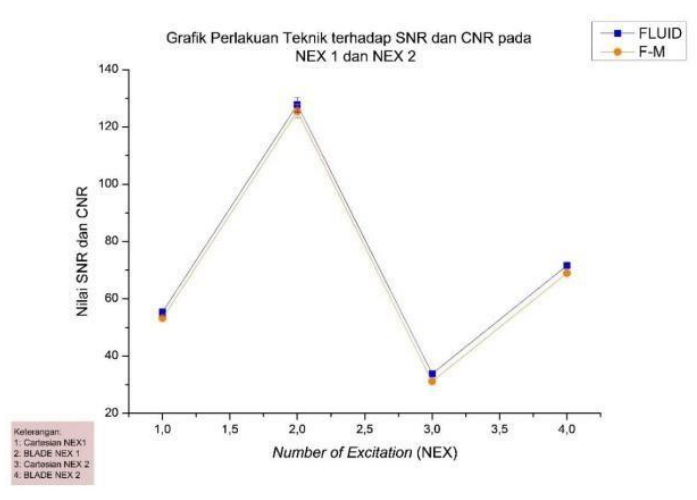

Gambar 4.13 Grafik

Hubungan Pengaruh Teknik

Cartesian dan Teknik 
BLADE terhadap Nilai SNR dan CNR pada NEX 1 dan NEX 2 pada pasien 3.

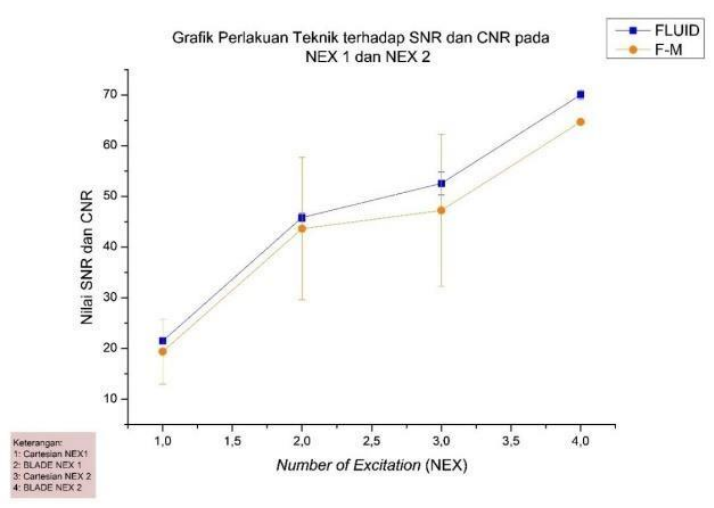

Gambar 4.14 Grafik

Hubungan Pengaruh Teknik

Cartesian dan Teknik BLADE

terhadap Nilai SNR dan CNR pada

NEX 1 dan NEX 2 pada pasien 4.

Dari hasil grafik di atas pengaruh

variasi NEX dan perlakuan teknik

terhadap

nilai SNR dan CNR pada keempat pasien dapat terlihat pada Tabel 4.9 sampai 4.12.

Tabel 4.9 Hasil Nilai SNR dan CNR dengan Variasi NEX dan Perlakuan

Teknik Pasien 1.

\begin{tabular}{|c|c|c|c|}
\hline NEX & Teknik & \multicolumn{1}{|c|}{ SNR } & CNR \\
\hline 1 & Cartesian & $64,96 \pm 4,82$ & $59,66 \pm 4,3$ \\
\hline 1 & BLADE & $98,29 \pm 3,11$ & $93,91 \pm 3,02$ \\
\hline 2 & Cartesian & $84,94 \pm 2,70$ & $82,04 \pm 2,12$ \\
\hline 2 & BLADE & $130,71 \pm 2,92$ & $125,16 \pm 2,81$ \\
\hline
\end{tabular}


Tabel 4.10 Hasil Nilai SNR dan CNR dengan Variasi NEX dan Perlakuan

Teknik Pasien 2.

\begin{tabular}{|c|c|c|c|}
\hline NEX & Teknik & SNR & CNR \\
\hline 1 & Cartesian & $29,36 \pm 0,61$ & $27,25 \pm 0,56$ \\
\hline 1 & BLADE & $44,08 \pm 0,92$ & $41,28 \pm 0,64$ \\
\hline 2 & Cartesian & $43,81 \pm 2,61$ & $40,55 \pm 7,15$ \\
\hline 2 & BLADE & $66,95 \pm 1$ & $61,81 \pm 0,85$ \\
\hline
\end{tabular}

Tabel 4.11 Hasil Nilai SNR dan CNR dengan Variasi NEX dan Perlakuan

Teknik Pasien 3.

\begin{tabular}{|c|c|c|c|}
\hline NEX & Teknik & SNR & CNR \\
\hline 1 & Cartesian & $55,35 \pm 1,33$ & $53,22 \pm 0,70$ \\
\hline 1 & BLADE & $127,70 \pm 2,63$ & $125,47 \pm 2,37$ \\
\hline 2 & Cartesian & $33,85 \pm 0,56$ & $31,19 \pm 0,40$ \\
\hline 2 & BLADE & $71,59 \pm 1,05$ & $68,95 \pm 0,55$ \\
\hline
\end{tabular}

Tabel 4.12 Hasil Nilai SNR dan CNR dengan Variasi NEX dan Perlakuan

Teknik Pasien 4.

\begin{tabular}{|c|c|c|c|}
\hline NEX & Teknik & SNR & CNR \\
\hline 1 & Cartesian & $21,51 \pm 0,63$ & $19,41 \pm 0,31$ \\
\hline 1 & BLADE & $45,84 \pm 0,80$ & $43,63 \pm 0,63$ \\
\hline 2 & Cartesian & $52,55 \pm 2,23$ & $47,22 \pm 1,56$ \\
\hline 2 & BLADE & $70,01 \pm 0,88$ & $64,67 \pm 0,41$ \\
\hline
\end{tabular}

Dari Gambar 4.11 sampai Gambar 4.14 dan Tabel 4.9 sampai Tabel 4.12 dapat dilihat bahwa nilai SNR ada perbedaan yang signifikan pada setiap variasi nilai NEX dan perlakuan teknik, hal ini disebabkan karena setiap pasien memiliki jumlah atom Hidrogen yang berbeda-beda, sehingga intensitas sinyal yang didapat disetiap jaringannyapun berbeda. Komposisi dari atom Hidrogen pada setiap jaringan tersebut dapat juga dipengaruhi oleh faktor usia dan dalam penentuan kualitas citra akan dikatakan baik ketika menghasilkan nilai SNR dan CNR yang tinggi dengan waktu scanning yang optimal.

\subsection{Pengaruh dan Penentuan}

Nilai Optimal Variasi dan

\section{Perlakuan Teknik terhadap}

\section{Nilai Artifact}

Pada penelitian ini terdapat motion artifact yang teramati ketika menggunakan teknik Cartesian. Motion Artifact adalah artefak akibat pergerakan yang dilakukan oleh pasien yang kemudian menghasilkan 
(C) (2019) Sekolah Pascasarjana Universitas Airlangga, Indonesia

penurunan pada kualitas citra MRI,

dapat dilihat pada gambar 4.15:
Pada Gambar 4.15 terlihat motion

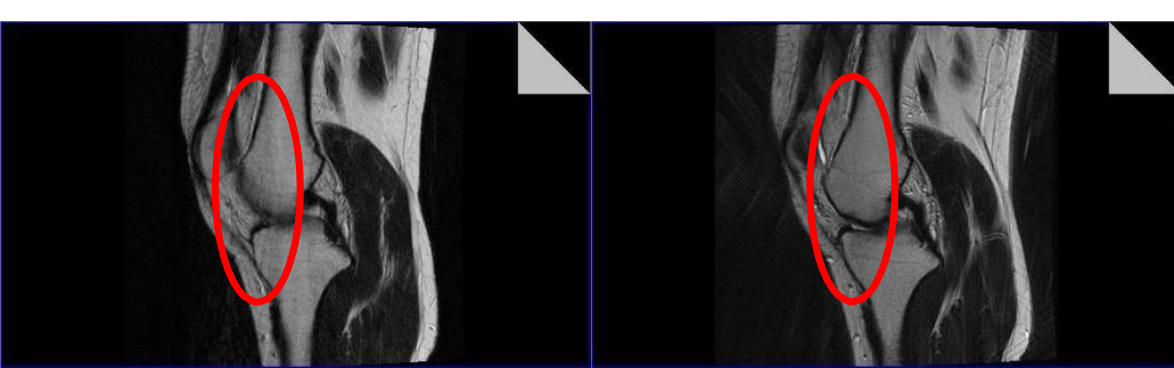

artifact muncul pada gambar (a) sehingga

$$
\begin{aligned}
& \text { ( } \\
& \text { ) } \\
& ( \\
& \text { b } \\
& \text { ) }
\end{aligned}
$$

Gambar 4.15 Perbedaan dua

teknik terhadap motion artifact (a)

Cartesian (b) BLADE (Kamera Digital). nenutupi area jaringan fluid, dimana ambar (a) tersebut menggunakan teknik Fartesian. Sedangkan pada gambar (b) rea jaringan fluid dapat diamati karena motion artifact berkurang akibat perlakuan teknik BLADE. Untuk nilai optimalnya sendiri pada setiap pasien dapat dilihat pada Gambar 4.16 sampai 4.19 dan Tabel 4.13 sampai 4.16: (a)

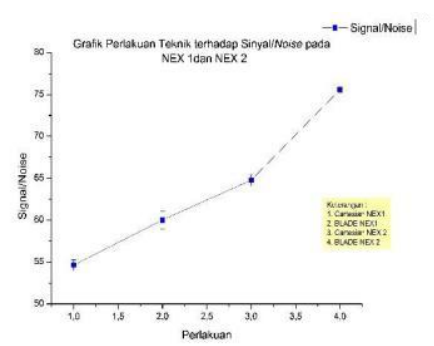

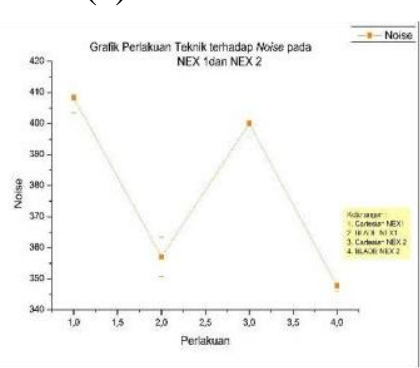

(b)

\begin{tabular}{|l|l|l|l|l}
\hline 1 & Cartesian & $408,3 \pm 4,9$ & 7,8 & 7,5 \\
\hline 1 & BLADE & $357,1 \pm 6,4$ & 6,6 & 5,7 \\
\hline 2 & Cartesian & $400,0 \pm 4,4$ & 5,2 & 6,2 \\
\hline 2 & BLADE & $347,7 \pm 1,8$ & 3,6 & 4,7 \\
\hline
\end{tabular}

Gambar 4.16 (a) Grafik Perlakuan Teknik terhadap Sinyal/Noise pada NEX 1 dan

NEX 2, (b) Grafik Perlakuan Teknik Terhadap Noise pada NEX 1 dan NEX 2.

Tabel 4.13 Hasil Nilai Noise dengan Variasi NEX dan Perlakuan Teknik untuk

Pasien 1.

\begin{tabular}{|c|c|c|c|c|c|c|c|}
\hline NEX & Teknik & Noise & \multicolumn{3}{|c|}{ ROI Background } & \multirow{2}{*}{ Rerata } & \multirow{2}{*}{ Sinyal/Noise } \\
\cline { 2 - 4 }
\end{tabular}




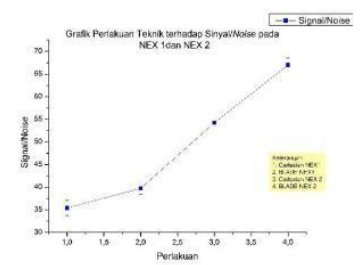

(a)

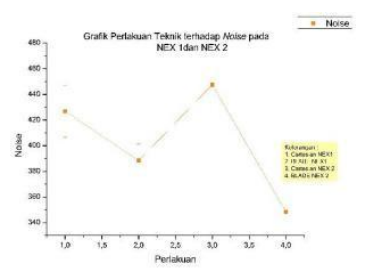

(b) 
(C) (2019) Sekolah Pascasarjana Universitas Airlangga, Indonesia

Gambar 4.17 (a) Grafik Perlakuan Teknik terhadap Sinyal/Noise pada NEX 1 dan

\begin{tabular}{|c|l|l|c|c|}
\hline 1 & BLADE & $388,4 \pm 12,8$ & 11,0 & 11 \\
\hline 2 & Cartesian & $447,5 \pm 13,9$ & 0,7 & 10 \\
\hline 2 & BLADE & $348,3 \pm 8,2$ & 5,8 & 5, \\
\hline
\end{tabular}

NEX 2, (b) Grafik Perlakuan Teknik Terhadap Noise pada NEX 1 dan NEX 2.

Tabel 4.14 Hasil Nilai Noise dengan Variasi NEX dan Perlakuan Teknik untuk

Pasien 2.

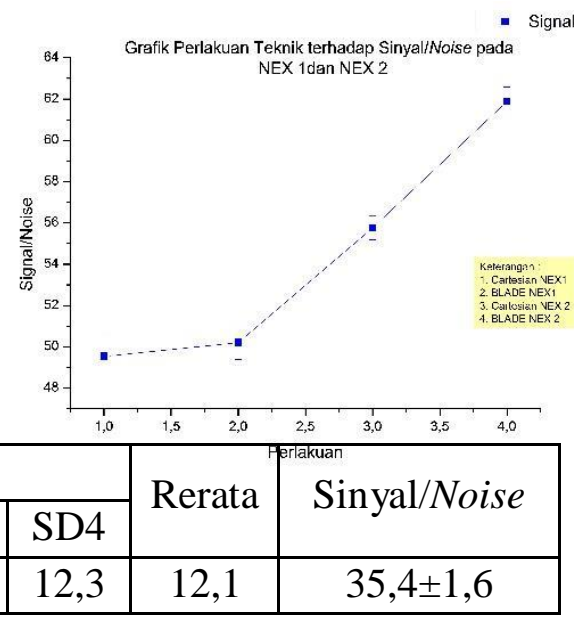

(a)

(b)

Gambar 4.18 (a) Grafik Perlakuan

Teknik terhadap Sinyal/Noise pada NEX 1 dan

NEX 2, (b) Grafik Perlakuan Teknik

Terhadap Noise pada NEX 1 dan NEX 2.

Tabel 4.15 Hasil Nilai Noise dengan Variasi NEX dan Perlakuan Teknik untuk

Pasien 3.

\begin{tabular}{|c|c|c|c|c|c|c|c|c|}
\hline \multirow{2}{*}{ NEX } & \multirow{2}{*}{ Teknik } & \multirow{2}{*}{ Noise } & \multicolumn{4}{|c|}{ ROI Background } & \multirow{2}{*}{ Rerata } & \multirow{2}{*}{ Sinyal/Noise } \\
\hline & & & SD1 & SD2 & SD3 & SD4 & & \\
\hline 1 & Cartesian & $346,75 \pm 7,4$ & 6,9 & 6,0 & 7,0 & 8,1 & 7,0 & $49,5 \pm 1,0$ \\
\hline 1 & BLADE & $382,77=6,2,2$ & 7,3 . & 7,8 & $=0$ & 7,9 & 7,6 & $50,2 \pm 0,8$ \\
\hline 2 & Cartesian & $444,7 \pm 4,6$ & $8,1^{\prime \prime}$ & 7,9 & 7,7 & 8,2 & 7,9 & $55,7 \pm 0,5$ \\
\hline 2 & BLADE & $442,47 \pm 5,1$ & $=8,1^{\frac{1}{2}} \mathrm{cos}$ & 6,2 & $6,7=$ & 7,6 & 7,1 & $61,8 \pm 0,7$ \\
\hline
\end{tabular}


Teknik untuk

Pasien 4.

Dari Gambar 4.14 sampai 4.17 dan Tabel

4.13 sampai 4.16 dapat diketahui

bahwa untuk mengurangi motion

artifact yang optimal adalah

dengan menggunakan teknik

BLADE

\section{DAFTAR}

\section{PUSTAKA}

Alibek S, Adamietz B, Cavallaro A, et al. Contrast enhanced T1weighted fluid- attenuated inversion-recovery BLADE magnetic reso-nance imaging of the brain: an alternative to spinecho technique for detection of brain lesions in the unsedated pediatric patient? Acad Radiol 2008;15:986-95.

Bushberg J.T., Seibert J.A., Edwin M. Leidholdt, J.R., Boone J.M., 2002, The Essential Physic of

Ga

mba

$\mathbf{r}$

\subsection{9}

(a)

Graf

ik

Perl

akuan Teknik terhadap

Sinyal/Noise pada NEX 1 dan

NEX 2, (b) Grafik Perlakuan

Teknik Terhadap Noise pada NEX

1 dan NEX 2. Medical Imaging, Second Edition, Lippincott Williams \& Wilkins, Philadelphia USA.

Bjørnerud, Atle. 2008. The Physics of Magnetic Resonance Imaging. Department of Physics University of Oslo.

Sumatera Utara, 4-24. 
Woodward, Peggy ang William, W. Arrison, 1997, MRI Optimization, a hand on approach, McGraw-Hill

J.Blink,Evert. 2004. Basic MRI :

Physics. Netherlands

Lavdas E, Mavroidis P, Hatzigeorgiou V, Roka V, Arikidis N,Oikonomou G, et al.Elimination of motion and pulsation artifacts using BLADE sequences in knee MR imaging. Magn Reson Imaging 2012 In press.

NessAiver, 1996, All you really need to know About MRI Physics, University of Maryland Medical Center, USA

Pipe, J. G. (1999). Motion Correction With PROPELLER MRI : Application to Head Motion and Free-Breathing Cardiac Imaging, 969, 963-969.

Rochmayanti, D., Widodo, T. S., \& Soesanti, I. (2013).

Analisis Perubahan Parameter Number of Sinyals Averaged ( NSA ) Terhadap Peningkatan SNR dan Waktu Pencitraan pada MRI, 2(4).

Siemens. 2010. Physical

Principles, CS Training

Center MR Basics All

rightsreserved. Copyright (C) Siemens AG

Weishaupt.Dominik,

D.Kochli.Victor, Marincek.Borut. 2006.

How Does MRI Work? An Introduction the Physic and Function of Magneting Resonance Imaging. Heildelberg: Business Media. 
Jurnal Biosains Pascasarjana Vol. 21 (2019) pp

(C) (2019) Sekolah Pascasarjana Universitas Airlangga, Indonesia 